\title{
The Nationalism of "Wong Cilik": Reflection on the Ideology of Partai Demokrasi Indonesia-Perjuangan (PDI-P) in Central Java
}

\author{
Turtiantoro \\ \{turtiantoro@yahoo.com\} \\ Universitas Diponegoro, Indonesia
}

\begin{abstract}
This study aims to examine the concept of wong cilik's nationalism as the ideology of the Indonesian Democratic Party Struggle (PDIP). The question to be proposed is what does wong cilik's nationalism which literally mean the nationalism of the common people mean? To answer this question, I conducted interview with the members of the party in Central Java provincial level. In addition, I also did archival and documentary studies. This study found that the nationalism of wong cilik as an ideology refers to an idea that the party should serve the most under privileged segment of the society as its main constituent. Wong cilik is then seen as the basic building of nationalism of an ideology. All of the members of the PDIP share comradeship and brotherhood by imagining themselves as sharing the same destiny as underprivileged people. This idea is then implemented in the programs and activities of the political party when approaching the members at the grass roots level. The approach manifests both in providing help in term of financial supports as well cultural approach.
\end{abstract}

Keywords: Nationalism, Wong Cilik, Ideology, Political Party

\section{Introduction}

Nationalism is an understanding which holds that the highest loyalty of each individual must be left to the nation state [1]. The term nationalism was first used in 1783 by Agustin Barruel, a French priest who in the mid-nineteenth century began to be widely known as a doctrine or political movement in Europe [2]. In the past loyalty was open to the nation-state but to various forms of social power such as landlords, tribal chiefs, kings, dynasties or religious elites. Ernest Renan defines the nation as a group of people who want to unite, who feel themselves united and Otto Bauer said the nation is a unity of temper that arises because of the union of fate. Sukarno said that at that time a new science had not yet arisen called geopolitics while criticizing Ernest Renan and Otto Bauer who only saw the nation of their people while Sukarno said how important was the union between people and places, the union between humans and their places, namely the motherland, land and water. is one unit " [3]. This Indonesian nationality has continued to be developed since before independence which in 1928 became one of the three pledges of Indonesian youth: One Nusa, One Nation, One Language.

The study of ideology reveals that the nature of ideology is very complex. Usually scientists choose one of two groups of thought; ideology negatively or neutrally [4]. Negative groups see ideologies that are fought for due to emotional factors and extreme irrational 
thinking [4]. Nationalism is criticized because unlike other religions it has never given birth to its own great thinking, nationalism does not have figures such as Thomas Hobbes, Alexis de Toqueville, Karl Marx, or Max Weber [5]. However, in Indonesia, nationalism in various periods of time gained a special place because it was always associated with the struggle to obtain and maintain independence and maintain the integrity of the Unitary State of the Republic of Indonesia.

At the beginning of the proclamation of independence, Indonesia needed the support of all elements of society in defending the country and the image of the international world as an understanding of democracy. Through the Government's Declaration on November 3, 1945 (Vice President's Declaration) on the formation of political parties the will and hope were formulated as follows:

a) The government likes the emergence of political parties because with the existence of political parties that can be led to the regular path of all political currents that exist in society;

b) The government hopes that the political parties will be organized before the election of the members of the House of Representatives is held in January 1946 [6].

In a short time, the public response was very enthusiastic marked the establishment of political parties. Compared with the ideological family introduced by Sukarno in 1926, the flow of ideology $\mathrm{i}$ experienced rapid and fragmentary developments. In addition to pointing to the Marxist political parties of the Indonesian Communist Party (PKI) also the Party of Murba (Deliberation of the Many People), the Indonesian Socialist Party (PSI) and the Young Communist Force (Acoma), each of which has a different style of struggle. Nationalist groups include the Indonesian National Party (PNI) as a radical nationalist, the Greater Indonesia Party (PIR) Wongsonegoro which is more noble and a series of small parties oriented to the two parties mentioned above such as the National People's Party (PRN), the Pancasila Defenders Movement (GPP) ), Indonesian People's Party (PRI), Marhaen Indonesia People's Association (Permai). From the Islamic circles include the Masyumi Party, the Nahdlatul Ulama Party, the Indonesian Islamic Syarikat Party, the Tarbiyah Islamiah Movement, the Islamic Bounded Political Party while from the Christians there is the Indonesian Christian Party (Parkondo), and the Catholic Party [6].

Results 1955 election to members of the House put 28 political parties and one individual getting a seat at once saw proof of how fertile the fragmentation of ideology since issued Notices Government of November 3, 1945. Four party politics appear to assure that the acquisition of the first PNI 8,434,653 votes (22.32\%) with 57 seats, secondly Masyumi $7,903,886$ votes $(20.92 \%)$ with 57 seats, NU 6,955,141 votes $(18.41 \%)$ with 45 seats, and PKI $6,176,914$ votes $(16.36$ votes \%) with 39 seats. The formation of the people's representative's election result in 1955 represents a new chapter in the conflict polities, rivalry and competition spanning some ten years later, was not able to empower national spirit characterized the movement of separatism that erupted in various areas, culminating in the tragedy of 1965.

\section{Result and Discussion}

\subsection{PDI-P Achieved Momentum}

At the beginning of the New Order era, the role of parties declined sharply as the policy of depoliticization and restructuring of political parties was pushed through the concept of 
"floating mass" which broke the chain of relations and activities of political parties to villages except Golkar who freely moves to use the bureaucracy and the military. In 1980s about $70 \%$ of the population is rural so since "floating gold" applied the result was predictable. The people only politicize once every five years, among them is for development. Golkar created New Order as a political vehicle since the 1971 elections sauntered up to the stage of power because bolstered the ranks of the military and bureaucracy from the center to the Sar $h$ including the village and it lasts until the next elections culminating in the 1997 election.

The Indonesian Democratic Party (PDI) which is the result of fusion from the PNI, Murba, IPKI, Parkindo, the Catholic Party which in its work carries the spirit of nationalism in the fact that several times the election remains a distended party. But, PDI never lost the sense to find a gap from being attacked political opponents as leftist, save meeting political jargon Marhaenisme, introducing jargon just as the party was "underprivileged", the party flip-flops, which are essentially to attract the sympathy of the Marhaen, followers of Sukarno and those who were marginalized by the New Order. PDI found momentum when Sukarno's children such as Guruh Sukarnoputra and Megawati Sukarnoputri began to take part in the political battle in the 1992 elections and resulted in attracting the sympathy of young people. Efforts to raise awareness that fear must be fought, young people must rise up against the fear created by the authorities and this resistance model seems to be on target proven in 1992 PDI was able to boost up the voice by adding 16 seats but at the same time became a threat to the ruler or Golkar and they have an interest to shake PDI solidity.

Megawati's sitting as Chairperson of the DPP PDI remains seen by the government as well as raising fears of the rise of political opponents and especially the rise of Sukarnoism which was clearly a group that was suppressed by the New Order, which ended in the tragedy of July 27, 1996. Unfair treatment the government against Megawati's camp made the momentum of the 1997 election be used to test loyalty and militancy. Megawati took the stand not to vote, did not use her right to vote, and her supporters were allowed to follow her conscience. Megawati's loyalty and militancy test had a significant impact. PDI Soerjadi's stronghold supported by the government and participating in the election lost many votes. In 1992 there were 56 seats in the DPR in the 1997 elections, only 11 seats left.

The Suharto ethic fell in 1998, according to Dirk Tomsa, only a few observers were convinced that Indonesia was able to build a stable democracy [7]. The election of 1999 were conducted in order to obtain a new political legitimacy, managed to change the political map that is six times previously won by Golkar, this time PDI in early 1999 became PDIPerjuangan led by Megawati emerged as the winner, but do not make the political temperature decreases. The practice of Indonesian politics after Habibie was replaced by Gus Dur was also not smooth. The Political Logic of the 1999 election which was participated by 48 parties and won by PDI-Perjungan with the acquisition of $35,689,073$ votes or $33.74 \%$ (153 DPR seats) was to give Megawati the first opportunity to occupy the position of President but the facts speak otherwise. Opposition wars, arguments, and even fatwas of some religious leaders milling about in the media stating that the state is led by women is forbidden because the leader (Imam) is male. Aspirations that reflect the will to turn away from Pancasila as the basis of the state illustrate that the rivalry and competition that confuses religion and politics or the politicization of religion as happened in the era of democratic parliamentary turns out to be repeated in the era of reform. Abdurrahman as the PKB General Chairman with 13,336,982 votes or $12.61 \%$ spearheaded by Amin Rais from the National Mandate Party formed the Central Axis coalition, overturned political logic and succeeded in winning the presidential election battle. 
Reaction defeat in the election of President Megawati, who was carried MPR shows a picture of how militant, loyal and emotional PDI-P cadres in Central Java after knowing the fate of their leaders. The Surakarta City Hall was burnt down by the masses, in various regions cadres and masses gathered to show solidarity and loyalty to the party leadership by holding banners that were used as thumbprints with blood. In the city of Semarang, the Gotongroyong Command Post, whose building is quite sturdy, is located on Street of Majapahit at the end of Street of Kimar, tied with steel ropes to be dragged by a truck until it falls apart. The wise attitude of Megawati and PDI-Perjuangan was shown to the public when accepting the decision of the MPR in his position as Vice President. Gus Dur's rise as president was quite short because there was a conflict with the DPR due to Gus Dur's leadership style which was difficult to influence or control by the supporting party. Not until half the term of office, Wahid was dropped and replaced by Megawati as President with Hamzah Has as Vice President. Severe challenges arise ahead of the 2004 elections.

The euphoria of the PDI victory in the 1999 elections including in Central Java made it difficult to consolidate, internal conflicts occurred, divisions were difficult to prevent. Many cadres who sit in political positions are also disappointing. In 2002 Erros Djarot and his colleagues established the Independence Bull Nationalist Party (PNBK), as well as other elites such as Prof. Dr. Dimyati Hartono, SH declared the Indonesian Party of Our Homeland (PITA), besides that Rahmawati Soekarnoputri also appeared by establishing the Pioneer Party. In 2006 Admiral Sukardi, Roy. BB Yanis, Sukowaluyo Mintohardjo founded the Renewal Democratic Party (PDP), all of which were a splinter from PDIP. Rivalry and intense competition between elites tends to divide the party vertically and horizontally from the center to the regions, but for Central Java the impact of the split is not significant. Although nationally twice the election failed to bring Megawati to the President, the results of the Central Java elections despite fluctuations are still able to maintain the position as the largest contributor of votes. After the defeat in the presidential and vice-presidential elections in 2004 and 2009, in 2014 PDIP again won victories for the legislature and the President/Vice President. In the Central Java DPRD, the PDI-P is still able to defend itself as the majority owner, even in the 2019 elections, it was able to obtain 42 seats from the previous 24 seats.

\section{Conclusion}

Central Java is able to prove that it is a "Bull Cage" that cannot be separated from the party's ability to consistently guard and socialize its ideology through gradual education and training activities. In addition, it is carried out through work meetings, political gatherings and general meetings utilizing the General Election and General Election momentum, management changes, political speeches from party leaders, or in other words cadre formation is structurally and non-structurally. In addition, the strength or superiority of PDIP from an ideological perspective is that there are quite a number of structural and non-structural cadres who are loyal and militant at the bottom of the mass base, remaining loyal to the party even though they have little chance to rise to the party elite because of the limited quality of human resources However, PDI-Perjuangan consistently plays a role of self-actualization of "the underprivileged", able to build loyalty, militancy and pride as party cadres with a "PatronClient" relationship pattern that protects and strengthens party solidity. 


\section{References}

[1] H. Kohn, "Nasionalisme: Arti dan Sejarahnya, terj," Sumantri Mertodipura. Cet ke-4. Jakarta PT Pembang. dan Erlangga, 1984.

[2] A. Heywood, "Ideologi Politik: Se-buah Pengantar (I)," Yogyakarta: Pustaka Pelajar, 2016.

[3] Sukarno, Dibawah Bendera Revolusi (I). Jakarta: Dibawah Bendera Revolusi, 1965.

[4] A. Widjaja, Budaya politik dan pembangunan ekonomi. Lembaga Penelitian, Pendidikan dan Penerangan Ekonomi dan Sosial, 1982.

[5] B. Anderson, "Imagined Communities; Komunitas-Komunitas Terbayang, Yogyakarta." Insist Press, 2002.

[6] W. Puspoyo, F. S. Swantoro, and E. Suksmantri, Dari Soekarno hingga Yudhoyono, pemilu Indonesia, 1955-2009. Era Adicitra Intermedia, 2012.

[7] E. Aspinall and M. Mietzner, Problems of democratisation in Indonesia: elections, institutions and society. Institute of Southeast Asian Studies, 2010. 